\title{
POETIC FUNCTION OF TRUCK CONTAINER SIGNS IN INDONESIA
}

Fungsi Poetik Tulisan Bak Truk di Indonesia

\author{
I Dewa Putu Wijana \\ Faculty of Cultural Sciences Gadjah Mada University \\ idp_wijana@yahoo.com
}

Naskah Diterima Tanggal 8 Februari 2020-Direvisi Akhir Tanggal 20 Oktober 2020-Disetujui Tanggal 2 Desember 2020 doi: https://doi.org/10.26499/rnh.v9i2.2951

\begin{abstract}
Abstrak
Dalam upaya menemukan kenyamanan hidupnya, manusia tidak akan pernah berhenti melakukan berbagai hal terhadap segala sesuatu yang dekat dengan lingkungan hidupnya, termasuk terhadap bahasa yang merupakan alat komunikasi verbal yang paling utama. Untuk memenuhi kebutuhan estetis ini, mereka sering memanfaatkan kemampuan berbahasanya untuk memproduksi wacana-wacana yang estetis. Makalah ini akan berusaha menganalisis fungsi poetik wacana tulisan di bak-bak truk yang melintas di jalan raya seluruh Indonesia. Dalam usaha menciptakan wacana yang estetis, para penciptanya secara masif memanfaatkan formula-formula berirama, metafora, simile, kontradiksi, hiperbola, kata-kata ragam sastra.
\end{abstract}

Kata-kata Kunci: wacana, bak truk, tanda, estetika

\begin{abstract}
In the pursuit of life comfort, human beings will never stop to do various ways with everything close to their surrounding, and language as the primary means of communication is one of tools used to realize this purpose. For the sake of fulfilling, their aesthetic need, human beings often exploit their linguistic ability to produce aesthetic discourses. This paper will try to analyse the poetic functions truck container signs passed over roads in Indonesia. In order to create aesthetic signs, the creators massively exploit various types of rhyming formulas, metaphors, similes, contradictions, hyperboles, literary style diction.
\end{abstract}

Key words: discourse, container, sign, aesthetic

How to Cite: Wijana, I Dewa Putu. (2020). Poetic Function of Truck Container Signs in Indonesia. Ranah: Jurnal Kajian Bahasa. 9(2). 202-211. doi: https://doi.org/10.26499/rnh.v9i2.2936

\section{INTRODUCTION}

Akerstrom (2017, p. 420) stated that human being is creature of comfort. People always try through many ways to seek and achieve their life comforts which include food, dwelling, relationship, health and amusement as well. As far as amusement is concerned, people create many things, either verbal or nonverbal, which enable to entertain themselves for releasing their life burdens. With regards to verbal activities, human being as "homo loquen" (speaking creature) and homo luden (playing creature) composes various genres of verbal formulas, such as poem, song lyrics, proverbs, idiomatic expressions and others of having high aesthetic 
values. There are countless numbers of works up till now can be found that discuss on poetic devices used by poets in creating their literary works. With regard to Indonesian and Javanese, the profound analysis on them can be found on the work of Pradopo (2012), Teeuw (1980), Winarti (2015), Wijana (2017), etc. All of these works take literary works as their material objects. Accordingly, this paper will try to analyse one genre of discourse that is commonly not considered as literary works, but massively exploits aesthetic devices for achieving expression niceties in delivering their messages. The discourse genre is signs found in trucks passing over roads in Indonesia. The signs are mostly placed on truck's tail gates and on right or left sides, or other places of the vehicle.

Additionally, from a wide range of linguistic discussions on such topics, no articles found seriously discussing poetic function and related matters contained in the discourses even though they mention that linguistic or communicative functions will become one of their topic discussions. Among Indonesian researchers who conducted researches on this topics, Sudaryanto et al. (2019) was noted showing rather satisfying results. They sought to reveal three main issues, i.e. the languages (langue) used to create truck container signs, language functions and discourse genres of the truck container signs. There are three languages often used to create the signs. Those are Indonesian, Javanese and English, and these languages are used to deliver three communicative functions, i.e. expressive, cognitive, phatic and communicative in the form of three genre types, prayer, flash rhymes, idiom and song titles. In relation to communicative functions, Sudaryanto et al. (2019) did not mention the poetic function of the discourse.

Without any clear explanation, they seemed to include it into the expressive one. In fact, these functions were clearly separated in Jakobson's theory of language function (Jakobson, 1966). Other discussion concerning linguistic aspects of truck signs had been carried out by several researchers. Dewi (2004) did a brief study on several types of speech acts on signs of trucks found passing over Solo-Sragen ring road. Nasirudin (2014) tried to analysis several aspects of Indonesian truck signs' discourses, including forms, ideology and their functions. Research done by Ilmi (2015) tried to investigate the semantic aspects of truck discourse signs without clear attention of what semantic aspects her study will focus on. Finally, Julaikha (2019) focused her attention on graffiti that uses Indonesian, and limited her study on discourse types and functions. From all researches investigating language functions of truck container signs, none of them tried to explore the language devices exploited by the creators to create the aesthetic discourses. This matter will become the focus of this study. 
Other study using critical approach done by Andalas and Prihartini (2018) was more interested in looking at women representation reflected in the truck signs, in which women tend to be represented negatively in terms of money, love and sex. In terms of money and love, women are represented as taking advantage from men. In terms of sex, they can be either passive or active.

\section{THEORETICAL BASIS}

In communicating with others, human verbal means of communication play a very important part. There are only a few human activities that can be conducted without using language. Even for thinking, language is actually needed although it is not expressed. As such, up till now, no one can exactly number the communicative functions of languages that may serve in human life. To avoid complications, language experts made it simple. Some of them classify the functions into two types with different labels. For example, Buhler (1934) differentiated between "referential" and "emotive", Brown \& Yule (1989, p. 1-2) between "transactional and "interactional", Halliday (1970) between "ideational" and "interpersonal" and Lyons (1977) between "descriptive" and "social expressive". Implicitly we can infer that the poetic function belongs to the second part of those dichotomic classifications.

Meanwhile, Jakobson (1966, p. 350-359) proposed a more complex classifications. He mentioned six categories of language functions. Those are emotive function for expressing emotional feelings, conative function for asking interlocutor to do or not to do something, referential function for referring or speaking something, metalinguistic function for explaining internal aspect of a language, phatic function for building or ending the contact and poetic function for creating aesthetic verbal works. With regard to the last function, human languages are full of aesthetic expressions, including short formulas exploited in political slogan, advertising jingles, enterprise's catchy phrases, etc., including truck container signs that will be discussed in depth in this study.

\section{RESEARCH METHOD}

All data presented in this paper were obtained from website through google searching. Firstly, data that have characteristics of poetic language were distinguished from those that lack thereof. They were further classified along with the literary devices exploited by the sign creators. Several data might be viewed from many aspects that enable them to appear for more than once. For the ease of presentation they will be labelled with different number. 


\section{DISCUSSION}

Truck container signs are used by the creators to deliver various messages, such as careful driving, advice for well behaving, faithfulness, betrayals, hard working, low wages, etc. These messages are expressed by many types of discourses, and some of them are created through expressions bearing aesthetic values. Closed examination towards data collection revealed that there are several devices exploited by the sign creators to yield verbal aesthetic signs. Those devices are rhyming formulas, metaphors, simile, contradiction, hyperbole and diction.

\section{Rhyming Formulas}

Creating rhyming formulas seems to be one of the most prominent ways used by the creators to exploit poetic powers of truck signs. As far as this matter is concerned, the rhyming pattern can be differentiated into three types, i.e. assonance, alliteration and repetition. Assonance is created through the combination of two or more words that have the same vowels but different consonants, or conversely the same consonants but different vowels. Consider examples (1) to (3) below:

(1) Kalah playu, menang sangu. 'Lost in running, but win in provision'

(2) Ngelih tinggal sambat, ngelih kudu sebat. 'When you're hungry you complain, when you're hungry you ask for help'

(3) Ora nduweni, wis tau numpaki. 'Not the owner, but driving it once'

(4) Kerja keras bagai kuda. Sampai lupa orang tua, oh hati terasa durhaka. 'Work hard like a horse that you forget your parents, oh you will feel insubordinate'

Examples (1), (3) and (4) respectively play on the final vowel rhyming /u/ (playu 'running' and sangu 'provision'), /i/ (nduweni 'to posses the vehicle' and numpaki 'driving the vehicle to be associated with copulating with a woman') and /a/ (kerja 'work', kuda 'horse', lupa 'forget, and orang tua 'parents'). Meanwhile, example (2) plays on final consonant /t/ (sambat 'complaining' and sebat 'asking'). The other examples are (5) to (7) below:

(5) Pada akhirnya yang berjuang akan kalah dengan yang beruang. 'In the end, the struggler will lose against the have'

(6) Jangan ngebut karena maut tak seindah music dangdut. 'Do not overspeed because death is not as nice as dangdut music'

(7) Dhudu jarak sing nggawe pisah nanging sampean karo dee meneng-meneng nggawe kisah. 'It is not the distance that separate us, but you and him secretly have an affair' 
All the last three discourses (5), (6) and (7) exploit final rhyming of vowel consonant combination /ang/ (berjuang 'struggling' and beruang 'having money), /ut/ (ngebut 'over speed' and dangdut 'dangdut music') and /ah/ (pisah 'separate' and kisah 'tale/story' which is contextually translated into 'affair').

Unlike (1) to (7), in the following examples (8) to (11), the aesthetic element is created through alliteration, that is the same initial sound combination, /p/ in pergi ' $\mathrm{go} / \mathrm{went}$ ' and pulang 'go home/went home/back'; /1/ in lek 'if', lali 'forget' and lek 'if'; /p/ in pergi 'go', pagi 'morning', penghasilan 'income' and pas-pasan 'just enough' and /k/ in kukodok-kodok 'I explore' and kotangmu 'your bra'.

(8) Pergi dicari. Pulang dimarahi.

'When I went away, I was look for. When I went home, I was scolded'

(9) Lek seneng podo lali. Tapi lek susah podo takon posisi.

'When you're happy, you all forget, but when you're desperate, you ask everyone's position'

(10) Pergi pagi. Pulang petang. Penghasilan pas-pasan. 'Go early morning, come back late in the evening. Income is just enough'

(11) Kukodok-kodok kotangmu 'I explored your bra'

Subsequently, the rhyming formulas can also be created through repetition, such as shown in examples (12) to (16) below:

(12) Ngelih tinggal sambat, ngelih kudu sebat. 'When you're hungry you complain, when you're hungry you ask for help'

(13) Lebih baik hidup dari sampah daripada hidup jadi sampah. 'It is better living from garbage than living to become garbage.'

(14) Dua anak cukup. Dua istri bangkrut. 'Two children are enough, two wives are bankrupt'

(15) Dah lama gak gitu. Pas gitu gak lama. 'It had been a long time not doing it, but when I'm doing it, it does not last long.'

(16) Hati-hati di jalan. Yang di hati kapan jalan-jalan. 'Be careful on your way. The one in your heart, when will you take her strolling.'

Example (12) exploits repetition of ngelih 'hungry', (13) sampah 'garbage' and its metaphorical sense 'something useless', (14) dua 'two', (15) gitu 'doing that' to mean sexual intercourse and (16) hati 'to mean take care' and 'heart', and jalan 'road' and jalan-jalan 'take a walk, strolling'.

\section{Metaphor}

To enable talking about something that is difficult to conceive, human beings, with their language potentials, create various figurative expressions based on the similarity of the primary (literal) meaning of the source domain and the target domain (see Wijana, 2016, p. 56). Any 
expressions of which meaning cannot be directly reached by the verbal symbols used to express are called metaphor. The central role of metaphors as poetic device has been an object of studies of many literary experts (see Pradopo, 2012, p. 66-77). Consider examples (17) to (23) below:

(17) Cintaku kandas di uang jalan bro. 'My love failed because of my low provision money'

(18) Kalau hidupmu tak jadikan sholat sebagai penghapus dosa, maka dosa akan menghapus sholat dalam hidupmu.

'If your life does not make praying as a sin remover, then the sin will remove the praying out of your life'

(19) Jatuh cinta tak sekejam jatuh tempo.

'Falling in love is not as cruel as due date'

(20) Kebohongan menyelamatkanmu sementara, tapi menghancurkanmu selamanya. 'Falsehood will save you temporarily but shatters you forever'

(21) Cinta sejati tidak akan menjadi tua, meski dimakan usia.

'True love will not become old, although it is consumed by age'

(23) Putus cinta soal biasa. Putus rem mati kita.

'Broken love is usual, broken brake we will die'

(24) Dua mata saya. Hidung saya satu. Satu hati saya. Cuma buat kamu. 'My eyes are two, my nose is one. My heart is one. It is just for you'

(25) Ora usah dolanan barang nyelempit. Enake sakmenit. Rekosone sundul langit. Do not play hidden things. The pleasure is just for a minute, yet the misery is as if reaching the sky'

In example (17), love 'cinta' is conceived as a journey on ship that can run aground, and cannot move any further. In (18), sholat 'praying' resembles a remover or eraser that could erase dosa 'sin'. In (19), jatuh cinta 'falling in love' and jatuh tempo 'due date' are imagined as an accident and human beings are coerced by emotion. In (20), kebohongan 'falsehood' is considered both as a rescuer and destroyer. In (21), cinta sejati 'true love' is not different from the animates that can grow old. In (23), putus cinta 'broken love' is an abstract or metaphorical entity, while putus rem 'broken brake' is a concrete one. In (24). mata 'eyes' and hidung 'nose' are both physical, but hati 'heart' is non-physical organ because it concerns with someone's feeling. Finally, in (25), woman genital is metaphorically expressed as barang nyelempit 'hidden things'. This might constitute an advice for drivers to not use prostitution service due to the danger and misery it can bring to their health.

\section{Simile}

Similar to metaphor, simile is constructed by using comparison to express equality or inequality. With regard to truck container signs, the similes are created by using se-plus adjective, and tidak or tak plus se-plus adjective. Consider the following examples (26) to (29):

(26) Cintamu tak semurni solarku.

'Your love is not as pure as my diesel fuel'

(27) Cinta sopir hanya sebatas parkir.

'Driver's love is just as wide as a parking line' 
(28) Kukira cintamu sepanjang tol Cipali. Ternyata cintamu seperti tol Palikanci yang singkat menemani. 'I thought your love is as long as Cipali Tol road. But in fact, it is just like Palikanci tol, which is too short to accompany me'

(29) Cintamu tak seberat muatanku. 'Your love is not as heavy as my load'

From the last four examples, it is shown that the target domain love is compared to entities close to the driver's life. In (26), the precious human need is compared to the purity of fuel diesel, width of parking space (27), length of Cipali and Palikanci tol road (28) and weight of the load (29). In (30), the low wages the driver gets is never equal with the value of the soul they pawn on the road.

(30) Tak perlu kau tahu susahku di jalanan karena upahmu tak sebanding dengan taruhan nyawaku. 'You do not need to know my misery on the road because your wage is incomparable to my life stakes'

In the following (31), the deep of interlocutor's yearning is compared to the weight of truck's load:

(31) Beratnya rindu tak seberat muatanku. 'The deep of your yearning is not as heavy as my load'

Finally, in (32), the driver's hard work is intertextually compared to horse using one of Koes Plus' song entitled Ku Jemu 'I feel bored'. Because the discourse topic is presupposed to be already known by the discourse participants, it does not appear in the the truck signs (33):

(32) Kerja keras bagai kuda. Sampai lupa orang tua, oh hati terasa durhaka.

'Work hard like a horse that you forget your parents, oh you will feel insubordinate'

(33) Tak seburuk kau duga

'It is not as bad as you think'

\section{Contradiction}

Contradiction is a literary divice exploited by the truck sign creators to contrast in various ways the entities or realities they want to expose in the signs. There are semantically many types of opposition found that are contradicted by the creators. With regard to this matter, nonbinary opposition seems more dominant than the binary one. Examples (34), (35) and (36) exploit the gradable opposition mahal 'expensive' and murahan 'a cheap sort of', cukup 'enough' and bangkrut 'bankrupt' and seneng 'happy' and susah 'misery'. Example (37) contradicts directional opposition pergi 'go' and pulang 'come back' and cyclic temporal opposition pagi 'morning' and petang 'evening'. Example (38) opposes non-antonymic relations between pulang 'go home' and its negative form nggak pulang 'not go home'. In (39), the creator opposes a binary antonymic pair neraka 'hell' and sorga 'heaven'. 
(34) Setia itu mahal, makanya tidak bisa dilakukan orang murahan.

'Faithfulness is expensive, so it cannot be done by a cheap sort of person'

(35) Dua anak cukup. Dua istri bangkrut.

'Two children is enough. Two wives is bankrupt'

(36) Lek seneng podo lali. Tapi lek susah podo takon posisi

'When you're happy, you all forget, but when you're desperate, you ask everyone's position '

(37) Pergi pagi. Pulang petang. Penghasilan pas-pasan.

'Go early morning, come back late in the evening. Income is just enough '

(38) Pulang malu. Nggak pulang rindu.

'Going home you feel ashamed, not going home you feel longing'

(39) Nerakaku bukan urusanmu. Sorga belum tentu jadi milikmu. Jangan suka urusin urusan orang lain. 'My hell is not your business. Heaven is not certainly yours. Do not mind someone else's business.

However, in some cases the type of opposition used to create contradiction is not easy to formulate, such as found in the following example (40) between menyelamatkan seorang janda 'to save a widow' and menjandakan istri sendiri 'to make our own wife a widow'.

(40) Jangan karena ingin menyelamatkan seorang janda jadi menjandakan istri sendiri. 'Just because you want to save a widow, be careful not to make your own wife a widow'

\section{Hyperbole}

Hyperbole is a style used to exaggerate something to make it sound better, more exciting or more dangerous than it really is (Hornby, 2010, p. 751). For example, the expression of sak menit 'one minute' in (41) is a hyperbolize expression to describe the short pleasure of prostitution, and so does sundul langit 'to reach the sky' to exaggerate its anguish. In (42), to hyperbolize the busy daily activities of her father, the little daughter asks him to spare just an hour for her. This is certainly a very short time, and not enough for their togetherness.

(41) Ora usah dolanan barang nyelempit. Enake sakmenit. Rekosone sundul langit.

'Do not play hidden things. The pleasure is just for a minute, yet the misery is as if reaching the sky'

(42) + Kamu mau beli apa sayang.

'What do you want to buy, my child'

- Ayah bolehkah aku beli waktu ayah satu jam saja

'Father, may I buy your time just for an hour'

\section{Diction}

Word choice is one of many aspects that distinguished literary genres, especially poetry, from other kinds of register. Words used in poems characterized by their functions to build intimate relationship and evoke emotional feelings between the speaker and the addresser. To achieve this purpose, truck sign creators massively exploit the use of Indonesian colloquial pronouns, such as $a k u$ 'I', $k u$ - 'I', $-k u$ 'me', -mu 'you, your', kau- 'you', such as shown in examples (43) to (46) below:

(43) Aku tak menunggu jandamu lagi.

'I am no longer waiting for you to be a widow' 
(44) Jangan tuduh aku selingkuh. 'Do not accuse me of committing adultery'

(45) Melupakan ibadah itu neraka. Melupakan orang tua itu durhaka. Melupakanmu mana bisa. 'Forgetting praying is hell. Forgetting parents is rebellious. Forgetting you, how can I?'

(46) Tak seburuk kau duga. 'It is not as bad as you think'

The other common way done by the creators is choosing literary style vocabularies, such as kisah 'tale/story' instead of cerita 'story', tiada 'no' instead of its phrase equivalent tidak ada 'no/none', pandang 'view/stare' instead of lihat 'see', duga 'think' instead of kira 'guess', etc. Consider examples (47) to (50) below:

(47) KISS 'Kisah Indah Seorang Sopir' 'KISS 'A beautiful story of a driver'

(48) Tiada Kata Seindah Doa 'No word as nice as a prayer'

(49) Seburuk apapun kau pandang diriku, belum tentu kau lebih sempurna. 'No matter how bad you see me, it is not certain that you are more perfect'

(50) Tak seburuk kau duga. 'It is not as bad as you think'

\section{CLOSING}

In the pursuit of life comfort, human beings will never stop to do various ways using everything close to their surrounding, and language as the primary means of communication is one of the tools used to realize this purpose. As a result, people create many kinds of formula containing aesthetic values, such as poems, song lyrics, rhyming slangs, rhyming riddles, etc. In line with this phenomena, a lot of truck container signs show the fondness of human beings playing with their language. The truck sign creators massively exploit verbal devices to construct beautiful expressions, starting from phonological level through alliteration, assonance and repetition to yield rhyming formulas, metaphors, simile, contradiction and lexical diction. In many cases, these devices incorporate one with the others. As such, one piece of sign may contain two or more devices.

To fully comprehend the messages the creators intend to deliver, the sign readers should also provide themselves with knowledge of local and national culture in Indonesia in its broadest sense, i.e. everything that might be found and happened in Indonesia, such as songs, idiomatic and proverbial expressions, political events, etc. Without those knowledges, the signs such as shown in examples (50) to (53) below cannot be easily grasped even though the readers already understand the meanings of every single word constructing the sign formulas.

(50) Otot kawat balung besi. Tetap semangat cari rejeki.

'Wire muscle, iron bone. Always be energetic in looking for luck' 
(51) Dua mata saya. Hidung saya satu. Satu hati saya. Cuma buat kamu. 'My eyes are two, My nose is one. My heart is one. Just for you'

(52) Semarang kaline banjir. Penak sing nyawang timbang sing mikir. 'The river of Semarang was flooding. Better seeing than thinking'

(53) Kerja keras bagai kuda. Sampai lupa orang tua, oh hati terasa durhaka.

'Work hard like a horse that you forget your parents, oh you will feel insubordinate'

This work is just a preliminary study. Deeper studies using wider range of data from various perspectives, linguistics, stylistics and pragmatics are still required.

\section{BIBLIOGHRAPY}

Akerstrom, Lola A. (2017). Lagom. London: Headline Publishing Group.

Buhler, K. (1934). Sprachtheorie. Gustav Fischer: Jena.

Dewi, Maylani Nursita. (2014). Tindak Tutur pada Ungkapan Bak Truk di Sepanjang Jalan Ring Road Solo-Sragen. Undergraduate thesis. Universitas muhammadyah Surakarta.

Halliday, M.A.K. (1970). Language Structure and Language Function. in New Horizon in Linguitics, John Lyons (Ed.). Harmondsworth Middx: Penguin Books.

Hornby, A.S. (2010). Oxford Advanced Learner's Dictionary. Oxford University Press.

Andalas, Fajar Eggy \& Arti Prihatini. (2018). Representasi Perempuan dalam Tulisan dan Gambar Bak Belakang Truk: Analisis Wacana Kritis Multimoda terhadap Bahasa Seksis. Satwika. 2(1). https://doi.org/10.22219/js.v2i1.7018

Ilmi, Fiky Akmala. (2015). Aspek Semantik pada Wacana Grafity Bahasa Indonesia Bak Truk dan Implikasinya terhadap Pengajaran Bahasa Indonesia. Jakarta: Program Studi Pendidikan Bahasa Indonesia. Universitas Indra Prasta PGRI Jakarta.

Jakobson. Roman. (1966). Closing Statement: Linguistics and Poetics. In Style in Language. Thomes A Sebeok (Ed.) Massachusset: The MIT Press.

Julaikha, Siti. (2019). Analisis Wacana Bahasa Indonesia pada Grafiti Bak Truk. Tegal: Universitas Pancasakti Tegal.

Lyons, John. (1977). Semantics. Vol. 1. Cambridge University Press. https://doi.org/10.1017/CBO9781139165693

Nasirudin, M. (2014). Wacana Graffity Berbahasa Indonesia pada Bak Truk. Jember: Fakultas Ilmu Pendidikan Universitas Negeri Jember.

Pradopo, Rahmat Djoko. (2012). Pengkajian Puisi. Yogyakarta: Gadjah Mada Universitu Press.

Sudaryanto, Kresna Sugiarto \& Mita Restiana. (2019). Wacana Grafity Bak Truk dalam Bahasa Indonesia, Bahasa Daerah, dan Bahasa Asing. Deiksis. 11(03). 276-285. https://doi.org/10.30998/deiksis.v11i03.3778

Teew. A. (1980). Tergantung pada Kata. Jakarta: Pustaka Jaya.

Wijana, I Dewa Putu. (2017). Kebebasan Penyair: yang Dicapai dan yang Dikorbankan. Mencari Formula Baru Kritik Sastra Indonesia, Sudibyo \& Saeful Anwar (Eds.). Yogyakarta: Interlude.

Wijana, I Dewa Putu. (2016). The Use of Metaphors in Indonesian Plant Names. Language, Literature, and Society. Yogyakarta: Sanata Dharma University.

Winarti, Daru. (2015). Tembang Dolanan Masyarakat Jawa: Kajian Linguistik Antropologis. Disertasi Doktor Universitas Gadjah Mada. 